\title{
The Anti-Infectious Role of Sphingosine in Microbial Diseases
}

\author{
Yuqing $W u^{1}{ }^{1}$, Yongjie Liu ${ }^{1,2}$, Erich Gulbins ${ }^{1,3}$ and Heike Grassmé ${ }^{1, *}$ \\ 1 Department of Molecular Biology, University of Duisburg-Essen, Hufelandstrasse 55, 45122 Essen, Germany; \\ Yuqing.Wu@uk-essen.de (Y.W.); Yong-Jie.Liu@uk-essen.de (Y.L.); erich.gulbins@uni-due.de (E.G.) \\ 2 Department of Thoracic Transplantation, Thoracic and Cardiovascular Surgery, University of Duisburg-Essen, \\ Hufelandstrasse 55, 45122 Essen, Germany \\ 3 Department of Surgery, University of Cincinnati, 231 Albert Sabin Way, Cincinnati, OH 45267, USA \\ * Correspondence: heike.grassme@uni-due.de; Tel.: +49-201-723-2133
}

check for

updates

Citation: Wu, Y.; Liu, Y.; Gulbins, E.; Grassmé, H. The Anti-Infectious Role of Sphingosine in Microbial Diseases. Cells 2021, 10, 1105. https://doi.org/ $10.3390 /$ cells10051105

Academic Editor: Klaus Scholich

Received: 8 April 2021

Accepted: 30 April 2021

Published: 4 May 2021

Publisher's Note: MDPI stays neutral with regard to jurisdictional claims in published maps and institutional affiliations.

Copyright: (c) 2021 by the authors. Licensee MDPI, Basel, Switzerland. This article is an open access article distributed under the terms and conditions of the Creative Commons Attribution (CC BY) license (https:/ / creativecommons.org/licenses/by/ $4.0 /)$.

\begin{abstract}
Sphingolipids are important structural membrane components and, together with cholesterol, are often organized in lipid rafts, where they act as signaling molecules in many cellular functions. They play crucial roles in regulating pathobiological processes, such as cancer, inflammation, and infectious diseases. The bioactive metabolites ceramide, sphingosine-1-phosphate, and sphingosine have been shown to be involved in the pathogenesis of several microbes. In contrast to ceramide, which often promotes bacterial and viral infections (for instance, by mediating adhesion and internalization), sphingosine, which is released from ceramide by the activity of ceramidases, kills many bacterial, viral, and fungal pathogens. In particular, sphingosine is an important natural component of the defense against bacterial pathogens in the respiratory tract. Pathologically reduced sphingosine levels in cystic fibrosis airway epithelial cells are normalized by inhalation of sphingosine, and coating plastic implants with sphingosine prevents bacterial infections. Pretreatment of cells with exogenous sphingosine also prevents the viral spike protein of severe acute respiratory syndrome coronavirus-2 (SARS-CoV-2) from interacting with host cell receptors and inhibits the propagation of herpes simplex virus type 1 (HSV-1) in macrophages. Recent examinations reveal that the bactericidal effect of sphingosine might be due to bacterial membrane permeabilization and the subsequent death of the bacteria.
\end{abstract}

Keywords: sphingosine; sphingolipids; ceramide; sphingosine-1-phosphate; sphingosine kinases; infection; bacteria; viruses; fungi

\section{Introduction}

Sphingolipids are a class of inter-convertible bioactive lipids that have dynamic functions in cellular signaling and membrane composition. All sphingolipids consist of a hydrophobic sphingoid skeleton, which contains a hydrocarbon chain, an amine group, and two hydroxyl groups. The amine group is bound to a fatty acid that, depending on the sphingolipid, has a different chain length and degree of saturation. One of the two hydroxyl groups can be changed to a phosphate, phosphocholine, or carbohydrate [1]. It has long been understood that sphingolipids serve as structural components of cell membranes, but multiple recent studies have also described their crucial functions in the regulation of physiological and pathological processes [2-5]. The key molecules of sphingolipid signaling are ceramide, sphingosine, and sphingosine-1-phosphate (S1P), which are involved in very diverse cell processes, such as proliferation, endocytosis, necrosis, apoptosis, and migration [2,5-7] (Figure 1). Sphingolipids are also important membrane components for pathogens, which use these components as receptors to adhere to the host cell membrane. In addition, sphingolipids, particularly sphingomyelin and ceramide, together with cholesterol lipid rafts, act as signaling platforms for adherence and invasion receptors [8] (Figure 2). This review focuses on sphingosine and its role in infectious diseases, and briefly discusses ceramide — a bioactive sphingolipid—and its derivative, sphingosine-1-phosphate. 


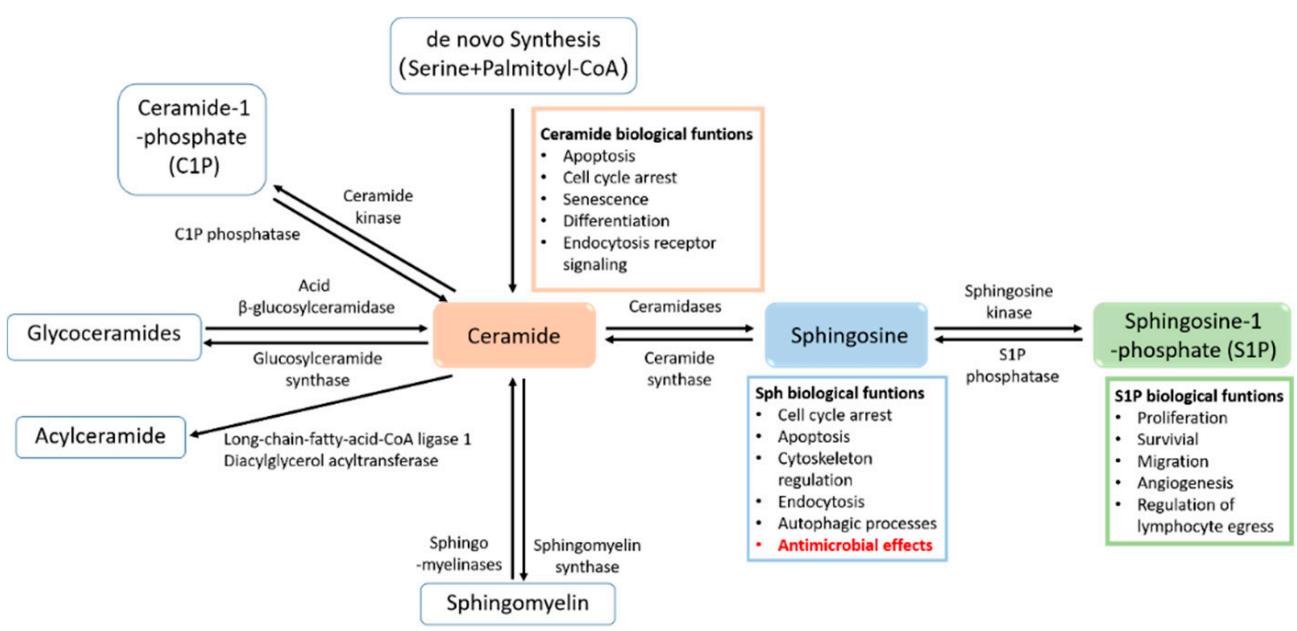

Figure 1. Sphingolipid metabolism and their biological functions. There are several pathways to synthesize ceramide. The de novo pathway generates ceramide after initiation with serine and palmitoyl CoA. Ceramides are then converted into other complex sphingolipids, including sphingomyelin, glycoceramides, and ceramide-1-phosphate. Ceramides can be acylated to acylceramide or deacylated by ceramidase to sphingosine. Sphingosine kinases phosphorylate sphingosine to sphingosine-1-phosphate. In turn, sphingolipid catabolic pathways result in ceramide from sphingomyelin, ceramide-1-phosphate, glycosphingolipids, and sphingosine. Ceramide, sphingosine, and sphingosine-1-phosphate are biologically active sphingolipids that are involved in several cellular processes.

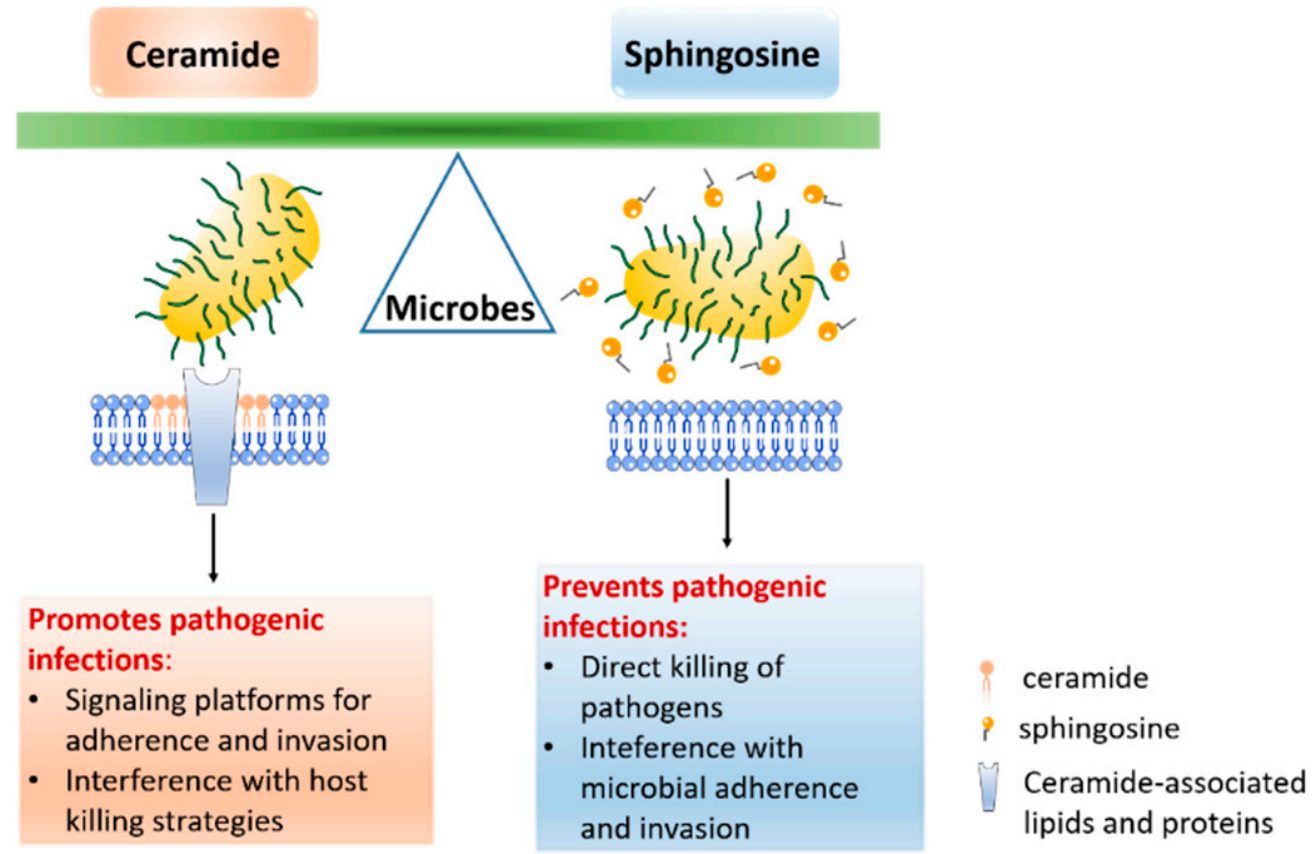

Figure 2. Model illustrating the different effects of ceramide and sphingosine on microbial infections. While sphingosine prevents many bacterial, viral and fungal infections, ceramide often promotes pathogenic infections, by mediating adhesion and internalization or by interfering with the killing strategies of the host. 
Ceramide is formed either by the hydrolysis of sphingomyelin through the activity of neutral, acidic, or alkaline sphingomyelinases or through de novo synthesis and/or the breakdown of complex sphingolipids. Several bacteria, viruses, and parasites exploit acid sphingomyelinase and/or the neutral sphingomyelinase-ceramide system to infect mammalian cells (for a recent review, see [9]). Ceramide enters a metabolic pathway and can be converted into sphingosine by the action of (acid) ceramidase. Sphingosine is further metabolized by phosphorylation via an ATP-dependent sphingosine kinase (Sphk), which leads to sphingosine-1-phosphate (S1P) [10].

Sphingosine 1-phosphate (S1P) regulates the proliferation, survival, and migration of mammalian cells through both extracellular receptor-mediated and intracellular mechanisms, either through intracellular targets or by activating a family of specific G-coupled receptors (S1PR) [11]. S1P is produced during inflammation and upon tissue damage, and it has well-described roles in cell signaling, the cell death/survival decision, and mediation of the pro-inflammatory response, including in the context of immunity [12]. An increasing number of reports describe the ability of pathogens, including mycobacteria, different viruses, and parasites, to dysregulate S1P signaling by modulating the Sphk/S1P axis reviewed in [13]. Therefore, agents targeting the generation of S1P are being actively developed as therapeutics for cancer and inflammatory and infectious diseases.

Sphingosine (Sph) constitutes a class of natural products containing a long aliphatic chain with a polar 2-amino-1,3-diol terminus (2-amino-4-trans-octadecene-1,3-diol). It occurs in the cell membranes of all animals and many plants and plays an important role in various complex biological processes, such as cell growth, differentiation, autophagic processes and development [14,15]. After its release from complex sphingolipids, sphingosine is mainly reacylated by ceramide synthase or phosphorylated by sphingosine kinase to generate sphingosine-1-phosphate [16] (Figure 1). Sphingosine has been connected with a variety of cellular processes, such as the induction of cell cycle arrest and apoptosis by modulating protein kinases and other signaling pathways [14]. It has roles in regulating the actin cytoskeleton and endocytosis, and has been shown to inhibit phosphokinase $C$ (PKC) [17]. In addition to its functions in cell signaling, sphingosine has broad-spectrum antimicrobial properties. The antimicrobial activity of sphingosine has been described for Gram-positive and Gram-negative bacteria [18], enveloped viruses [19], and fungi [20] (Table 1). Sphingosine's role as an antimicrobial is important in tissues such as the skin, respiratory epithelium, and the oral cavity. Chronic diseases, such as cystic fibrosis (CF), in which the normal sphingosine level is reduced in epithelial cells [21,22], are associated with problems related to high infection susceptibility. Therefore, exogenous sphingosine may be a successful antimicrobial therapeutic. Inhaled nebulized sphingosine has been shown to be effective in both preventing and treating pneumonia in multiple CF mouse models without producing severe toxic side effects [21-24]. 
Table 1. Microbes attacked by sphingosine.

\begin{tabular}{|c|c|c|}
\hline Microbes & Species & References \\
\hline \multirow{18}{*}{ bacteria } & Acinetobacter baumannii & [21] \\
\hline & Brevibacterium epidermidis & [25] \\
\hline & Burkholderia cepacia & [21] \\
\hline & Corynebacterium bovis & [18] \\
\hline & Corynebacterium striatum & [18] \\
\hline & Corynebacterium jeikium & [18] \\
\hline & Escherichia coli & {$[18,26,27]$} \\
\hline & Haemophilus influenzae & [21] \\
\hline & Micrococcus luteus & [25] \\
\hline & Moraxella catarrhalis & [21] \\
\hline & Neisseria gonorrhoeae & [28] \\
\hline & Propionibacterium acnes & [25] \\
\hline & Pseudomonas aeruginosa & {$[21,22,25,27,29-32]$} \\
\hline & Staphylococcus aureus & {$[18,23,25,27,29,33,34]$} \\
\hline & Staphylococcus epidermidis & [35] \\
\hline & Streptococcus mitis & [18] \\
\hline & Streptococcus pyogens & [25] \\
\hline & Streptococcus sanguinis & [18] \\
\hline \multirow{3}{*}{ viruses } & Hepatitis $C$ virus & [19] \\
\hline & Herpes simplex virus type 1 & [36] \\
\hline & $S A R S-C o V-2$ & [37] \\
\hline \multirow{4}{*}{ fungi } & Candida albicans & [25] \\
\hline & Epidermatophyton floccosum & [33] \\
\hline & Trichophyton mentagrophytes & [33] \\
\hline & Trichophyton tonsurans & [33] \\
\hline
\end{tabular}

\section{The Role of Sphingosine in Infectious Diseases}

\subsection{Sphingosine and Bacteria}

Since the middle of the last century, microbiologists have recognized that the skin is a natural barrier in the defense against microbial infections, and that skin lipids can reduce infections caused by Gram-positive bacteria $[33,38]$. However, due to methodological limitations and historical reasons, these lipids were not completely identified until the end of the 20th century. Since then, several reports on the broad-spectrum antimicrobial properties of sphingosine have been published. Sphingosine has been shown to have remarkably potent antibacterial activity against a variety of pathogens, including Pseudomonas aeruginosa, Staphylococcus aureus, Acinetobacter baumannii, Haemophilus influenzae, Burkholderia cepacia, Moraxella catarrhalis, Escherichia coli, Fusobacterium nucleatum, Streptococcus sanguinis, Streptococcus mitis, Corynebacterium bovis, Corynebacterium striatum, and Corynebacterium jeikeium $[20,21,23,26,33,39,40]$. Among these pathogens, Staphylococcus aureus and Pseudomonas aeruginosa are the most studied. Therefore, herein, we focus on the bactericidal effect of sphingosine, as well as the mechanisms behind it, on these two bacterial species.

\subsubsection{Staphylococcus aureus}

Staphylococcus aureus (S. aureus) is a ubiquitous and opportunistic Gram-positive coccoid bacterium, and a prevalent skin pathogen. It causes severe respiratory tract and 
systemic infections, especially among patients with previous viral infections, burn wounds, trauma, or sepsis; those requiring mechanical ventilation; and those with cystic fibrosis (CF) (for recent reviews, see [41,42]). Treating S. aureus infections is an increasing challenge due to multi-drug resistance against common antibiotics caused by methicillin-resistant Staphylococcus aureus (MRSA).

Bibel et al. first described the antimicrobial activity of the skin lipid sphingosine in 1992 [25]. The authors found that sphingosines were profoundly effective against $S$. aureus (strain 502A), with a $4-\log$ reduction at $20 \mu \mathrm{M}$ and a $2-\log$ reduction at $2.5 \mu \mathrm{M}$. The optimal inhibition was observed after $60 \mathrm{~min}$ incubation at $37^{\circ} \mathrm{C}$ and $\mathrm{pH} 6.5$, and the antimicrobial activity of sphingosines was $\mathrm{Ca}^{++}$dependent. Accordingly, Arikawa et al. found a significantly downregulated sphingosine level in patients with atopic dermatitis, which was caused by the decreased activity of acid ceramidase [39]. The decreased sphingosine level was associated with enhanced vulnerability to colonization by $S$. aureus in atopic dermatitis patients. Parsons et al. further reported that toxic fatty acids, including sphingosine, permeabilized the membrane and released the pathogen's intracellular ATP into the medium without causing complete dissolution of the cytoplasmic membrane or a significant morphological change [34]. Other groups observed that sphingosine caused multiple cell wall lesions, membrane evaginations, the loss of ribosomes, and ultrastructural damage in $S$. aureus through the use of electron microscopy [26,33].

In addition to skin infections, $S$. aureus infections often occur in chronic obstructive pulmonary disease (COPD) and cystic fibrosis (CF) patients [43-46]. Cystic fibrosis is a disease caused by mutations in the cystic fibrosis transmembrane conductance regulator (CFTR) protein, and it is the most widespread recessively inherited disorder in North America and Europe [46-49]. Notably, the most common cause of morbidity and mortality in CF patients is chronic pulmonary infection with bacterial pathogens, particularly Pseudomonas aeruginosa (P. aeruginosa) and S. aureus. [50]. CF mice showed a marked sphingosine reduction and ceramide accumulation in the respiratory tract due to the repressed activity of acid ceramidase $[21,45,51]$. Following the discovery of low levels of sphingosine in CF mice [21], Tavakoli et al. studied the bactericidal effect of sphingosine and ceramide on S. aureus (strain E25) in CF mice [23]. The authors confirmed that CF mice had a high susceptibility to $S$. aureus infection compared with wild-type mice. More importantly, inhalation of C18-sphingosine 30-40 min before infection could protect the CF mice from infection with $S$. aureus. This work was the first to report that sphingosine administered by inhalation acted against $S$. aureus in airways and could prevent airway infection. Based on these findings, the use of sphingosine on implanted medical devices was proposed to prevent staphylococcal infections $[29,35]$. About $25 \%$ of mechanically ventilated patients are affected by ventilator-associated pneumonia, which has an estimated mortality of $13 \%$ [52]. Both Gram-negative and Gram-positive bacteria cause ventilator-associated pneumonia, and S. aureus is the most common Gram-positive bacterium responsible for this disease [53] (we later discuss Gram-negative bacteria, specifically P. aeruginosa). Seitz et al. coated the plastic surfaces of endotracheal tubes with high sphingosine concentrations. As a result, the adherence and growth of methicillin-resistant S. aureus (MRSA) on the plastic surface were significantly reduced [29].

Along with S. aureus, Staphylococcus epidermidis (S. epidermidis) is a dominant skin colonizer and is prevalent in orthopedic infections. The inhibitory effect of sphingosine $(10 \mu \mathrm{M})$ on S. epidermidis was described by Beck et al. [35], who expanded the application of sphingosine to implant materials [35]. Periprosthetic infection is a devastating complication of joint replacement surgery, and results in bacterial biofilm formation [54]. Bacteria that adhere to implant surfaces produce a complex hydrated matrix of glycocalyx that coats the bacteria and forms a biofilm layer [55]. The authors generated S. epidermidis biofilms on different implant materials and determined the bactericidal effect of sphingosine on the formed biofilms. When a concentration of $100 \mu \mathrm{M}$ was used for coating, sphingosine eliminated at least $94 \%$ of the pathogens. Coating implant samples (titanium, steel, and 
polymethylmethacrylate) with sphingosine prevented implant contamination and resulted in a significant reduction in biofilm formation on the implant surfaces [35].

\subsubsection{Pseudomonas aeruginosa}

Pseudomonas aeruginosa (P. aeruginosa) is an opportunistic Gram-negative rod-shaped bacterium that, similar to $S$. aureus, is quite often associated with burn wounds, trauma, sepsis, cystic fibrosis, and chronic obstructive pulmonary disorders (COPD), and it causes significant infections in patients who need mechanical ventilation [43,44,56-58]. Worldwide, P. aeruginosa is known to be one of the most common Gram-negative pathogens associated with pneumonia [59] and is, in addition to $S$. aureus, the leading pathogen and main cause of death in CF patients [56-58,60-62].

The high susceptibility of cystic fibrosis mice and patients to $P$. aeruginosa infections was found to be significantly reduced by treatment with sphingosine, which is extensively downregulated in the tracheal and bronchial epithelia of cystic fibrosis patients and mice [21]. The inhalation of sphingosine restores the reduced sphingosine levels of CF tracheal and bronchial epithelia, thereby protecting mice from infection with $P$. aeruginosa (strain PA14, ATCC 27853, and ATCC 762).

In 2017, our group showed that the high susceptibility of cystic fibrosis patients and mice to $P$. aeruginosa, S. aureus, and Acinetobacter baumanii was related to $\beta 1$-integrin accumulation due to the increased ceramide level on the luminal membrane upper-airway epithelial cells in these hosts [22]. The results revealed that the accumulation of ceramide in cystic fibrosis cells trapped $\beta 1$-integrins in the luminal membrane of $\mathrm{CF}$ bronchial, tracheal, and nasal epithelial cells. Ectopic $\beta 1$-integrins in the luminal membrane downregulate the expression of acid ceramidase (which converts ceramide to sphingosine) in human and murine CF airway epithelial cells. Reduced acid ceramidase expression further mediates ceramide accumulation, thereby forming a positive feedback loop between ceramide and $\beta 1$-integrins with the concomitant depletion of sphingosine. The blockade of $\beta 1$-integrin and this vicious cycle normalizes sphingosine levels in epithelial cells from cystic fibrosis patients and cystic fibrosis mice and prevents them from developing severe P. aeruginosa infections. This work explained the low level of sphingosine in the cystic fibrosis model [22]. It remains unknown how $\beta 1$-integrin manipulates acid ceramidase and how CFTR deficiency leads to the $\beta 1$-integrin-mediated downregulation of acid ceramidase. Following the finding that sphingosine prevents infections in the cystic fibrosis model, sphingosine was also proven to prevent $P$. aeruginosa infections in other mice models, such as ceramidase synthase-2-deficient, aged, burn-injured, and septic mice [21,30-32]. Interestingly, the genetic deletion of sphingosine kinase (Sphk), which phosphorylates the lipid sphingosine to generate sphingosine-1-phosphate (S1P), also protected mice from P. aeruginosa-mediated lung inflammation $[63,64]$, further supporting an anti-bacterial effect of sphingosine, which very likely accumulated upon deletion of the kinase.

Fischer et al. investigated the uptake of several sphingoid bases, including sphingosine, by Escherichia coli (E. coli) and S. aureus and assessed their subsequent ultrastructural changes via electron microscopy. While sphingosine-treated $S$. aureus underwent drastic membrane disruption, the cytoplasmic and outer membranes of E. coli appeared to remain intact. Both E. coli and S. aureus cells contained unique internal inclusion bodies that may reflect lipid uptake [26]. These observations excluded the possibility that sphingosine kills bacteria by simple lysis or destruction of the pathogen structure. Recent findings from our group shed light on the mechanism of sphingosine-mediated bacterial killing [27]. The results indicate that sphingosine has an in vitro bactericidal effect on P. aeruginosa and S. aureus. Upon treatment with sphingosine, the permeabilization of the bacterial membranes, the release of intracellular ATP, decreased metabolic activity, and reduced bacterial survival were observed. This bactericidal effect depends on the $\mathrm{NH}_{2}$ group of sphingosine. $\mathrm{NH}_{2}$ groups can be protonated and are positively charged under neutral and slightly acidic $\mathrm{pH}$ [65]. This might explain the observation that sphingosine maintains its bactericidal activity only under neutral or acidic $\mathrm{pH}$, whereas this effect is profoundly reduced at alkaline 
$\mathrm{pH}$. Positively charged sphingosine $\mathrm{NH}_{2}$ groups interact with cardiolipin in pathogens and effectively kill bacteria, while bacteria that lack cardiolipin synthase are resistant to sphingosine treatment. Incorporating cardiolipin into membranes results in a negative curvature [66]. The killing mechanism mediated by the interaction between sphingosine and cardiolipin might be the following: when negatively charged cardiolipin binds to sphingosine, cardiolipin may aggregate and form rigid, gel-like membrane domains. These domains disturb the original membrane structure and lead to membrane permeabilization and bacterial death. This theory should be further verified.

\subsubsection{Neisseria gonorrhoeae}

Neisseria gonorrhoeae (N. gonorrhoeae) is a Gram-negative diplococcus and an obligate human pathogen. Gonococci are the causative agents of the sexually transmitted disease gonorrhea and have the potential to enter the bloodstream and cause systemic disseminated infections with severe consequences, such as endocarditis and arthritis [28,67,68]. An increasing number of reports are highlighting the threatening development of multidrugresistant gonococci; thus, new strategies are required to combat this pathogen. Solger et al. showed that $N$. gonorrhoeae was also sensitive to sphingosine treatment [68]. Treatment with $20 \mu \mathrm{M}$ sphingosine achieved a similar bacterial killing effect to the antibiotic kanamycin [68]. Mechanistically, it was shown that invasive N. gonorrhoeae strains ingest sphingosine from the host cell, which is evenly distributed on the surface of intracellular bacteria, and then incorporates it into the bacterial membrane. This leads to the decreased survival of $N$. gonorrhoeae and confirms that sphingosine can directly affect bacteria rather than activating other cellular bactericidal factors. However, whether sphingosine kills $N$. gonorrhoeae by interacting with cardiolipin, as in P. aeruginosa, is unknown and should be studied accordingly.

\subsection{Sphingosine and Viruses}

Viruses are obligate intracellular pathogens: they manipulate the host and exploit membranes and their components, such as sphingolipids, in all steps of their life cycle, including adhesion and membrane fusion, viral replication, and budding from host cells [69-71]. Human immunodeficiency virus (HIV), measles virus (MV), Ebola virus (EBOV), Sindbis virus (SINV), and rhinovirus [72-75] all exhibit sphingolipid-dependent virus entry by activating sphingomyelinases and making use of ceramides as adherence and signaling platforms.

Sakamoto et al. were the first to show that targeting hepatitis $\mathrm{C}$ virus (HCV) sphingolipid metabolism could inhibit viral replication and prevent infection [19]. They identified a new lipophilic long-chain base compound, NA255, which has a sphingolipid-binding motif that can directly interact with sphingomyelin. Hepatitis $C$ virus substantially affects lipid metabolism, and the remodeling of sphingolipids appears to be essential for $\mathrm{HCV}$ persistence in vitro. The quantification of serum sphingolipid variations in patients with acute HCV infection revealed that sphingosine and sphinganine levels were significantly upregulated in patients who were unable to clear the virus over time compared with patients who spontaneously cleared the infection [19]. The persistence of HCV after acute infection induces the downregulation of $\mathrm{C} 24$-ceramide and the simultaneous elevation of serum sphingosine and sphinganine concentrations [76].

Since then, the direct effect of sphingolipids on viruses has been rarely reported, which has only recently changed $[36,37]$. Lang et al. first reported that sphingosine blocked the propagation of herpes simplex virus type 1 (HSV-1) in macrophages [36]. They found that the restriction of HSV-1 reproduction was dependent on cellular acid ceramidase. HSV-1 is an enveloped DNA virus that replicates in several cell types [77]. After targeting a cell, HSV-1 either fuses with the cell plasma membrane or is taken up by the cell into endosomes, where fusion with the perimeter of membrane leads to infection [78-80]. Lang et al. showed that the deficiency of acid ceramidase led to the uncontrolled replication of HSV-1. In macrophages, acid ceramidase converts ceramide 
into sphingosine, which forms sphingosine-rich intraluminal vesicles that can bind to HSV-1 particles. This limits the fusion of HSV-1 with the endosomal membrane, prevents cellular infection, and releases the virus for lysosomal degradation. Correspondingly, macrophages treated with sphingosine blocked HSV-1 replication. This research was the first study that showed the direct antiviral effect of endogenous sphingosine [36].

Recently, some reports have been published on the role of lipid raft components in the infection of the severe acute respiratory syndrome coronavirus-2 (SARS-CoV-2) of host cells [81-83]. SARS-CoV-2 is the causative agent of coronavirus disease 2019 (COVID-19), which is associated with a high mortality rate [84]. SARS-CoV-2 infects cells using its viral spike glycoprotein, which interacts with human epithelial cells via its cellular angiotensinconverting enzyme-2 (ACE2) receptors [85-88]. Lipid rafts, which are membrane domains enriched with cholesterol and sphingolipids such as gangliosides, have been described as a perfect interface for the concentration of the ACE2 receptor on epithelial cell membranes, thus facilitating the interaction with the viral spike proteins [81-83]. Another exciting study showed that sphingosine plays a protective role against infection with SARS-CoV-2 [37]. Edwards et al. used pseudo-viral particles expressing SARS-CoV-2 spike (pp-VSV-SARSCoV-2 spike), serving as a bona fide system that mimics SARS-CoV-2 infection [37]. The study utilized Vero-E6 epithelial cells and freshly isolated human nasal epithelial cells to examine whether exogenous sphingosine prevents pp-VSV-SARS-CoV-2 infection of epithelial cells. The authors showed that pretreating cells with exogenous sphingosine blocked the interaction between the viral spike protein and ACE2 (Figure 3). This inhibition was achieved with a relatively low concentration of sphingosine (only $0.25 \mu \mathrm{M}$ ), and it could completely block the interaction between the spike protein and ACE2 receptor at $2 \mu \mathrm{M}$. At this concentration, sphingosine had no side effects or toxic effects on human nasal epithelial cells. Therefore, it provides a potential defense strategy against SARS-CoV-2 infection [37]. To date, it is still unknown whether sphingosine has a direct antiviral effect on SARS-CoV-2 or HSV-1.

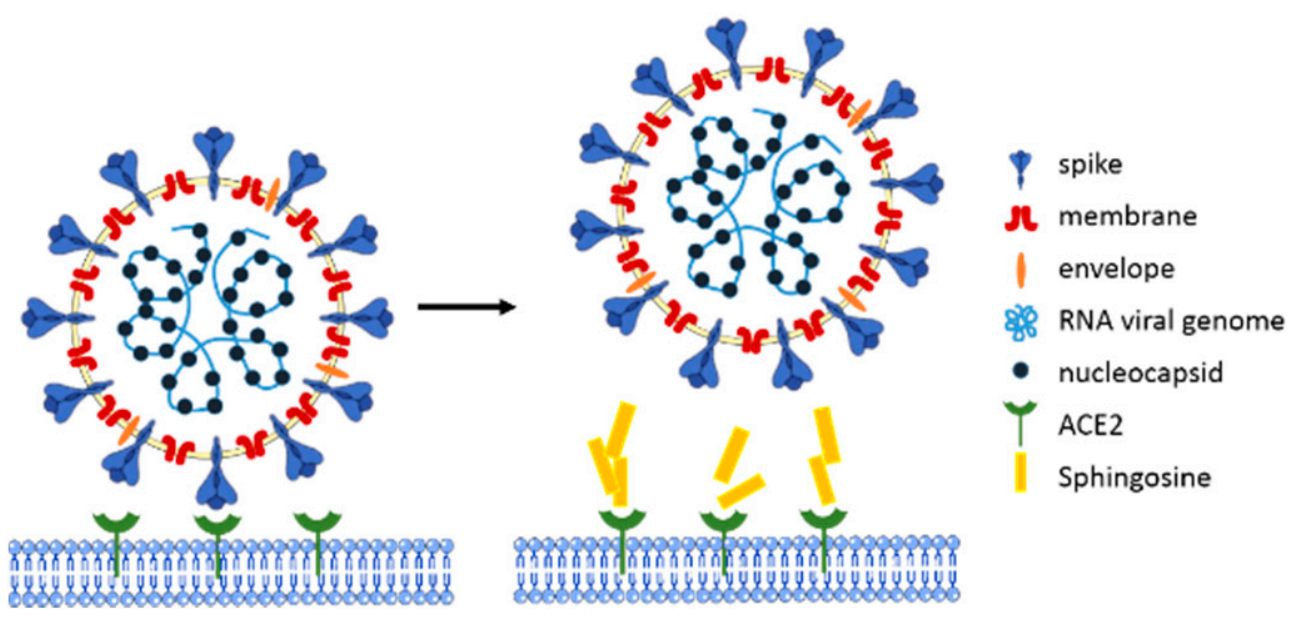

Figure 3. Model of how sphingosine prevents SARS-CoV-2 infection. Exogenous sphingosine application in human nasal or Vero-E6- epithelial cells results in the binding of sphingosine and angiotensin-converting enzyme 2 (ACE2) receptor, which is required for severe acute respiratory syndrome coronavirus-2 (SARS-CoV-2) infection. Sphingosine thereby prevents the recognition and interaction between the spike protein of SARS-CoV-2 and the host's ACE2 receptor and ultimately protects the cells from infection. 
Recent studies indicate that fingolimod (FTY720), a sphingosine analog, already approved for the treatment of multiple sclerosis (MS), may help prevent the more serious neurological side-effects of SARS-CoV-2 infection [89-91]. FTY720 requires sphingosine kinase (Sphk) for activation and phosphorylation and blocks the inflammatory reaction mediated by sphingosine-1-phosphate (S1P)/sphingosine-1-phosphate receptor (S1PR)1 [92,93]. Currently, as one of the most unique sphingolipid-based drugs, fingolimod has good potential to become an important drug in the treatment of COVID-19.

\subsection{Sphingosine and Fungi}

Fungal infections are increasingly coming into focus due to the continual rise of immune-deficient patients, such as those who have HIV / AIDS or take immunosuppressant medications. Cryptococcosis, candidiasis, and aspergillosis are severe invasive mycoses with high mortality in immunocompromised patients [94]. The fungal eukaryotic cell membrane contains sphingolipids, in addition to other components [95]. Because fungal sphingolipids have different chemical structures from those of mammalian sphingolipids, they can be exploited as targets for the development of antifungal drugs. Therefore, several studies have focused on sphingolipid metabolism in fungal cells for the development of new antifungal agents $[20,96]$. A variety of compounds have been reported to act against the fungal sphingolipid biosynthetic pathway. Such compounds include natural and synthetic molecules, such as fumonisin B1 as an inhibitor of ceramide synthase or FTY720 (fingolimod) as a sphingosine-1-phosphate antagonist, as well as antibodies, which can attenuate fungal sphingolipids $[20,96]$. In recent years, monoclonal antibodies against fungal glucosylceramides (GlcCer) have been developed and proven to inhibit cryptococcal growth in vitro [97]. Infection with Candida albicans was shown to be sensitive to inositol phosphorylceramide synthase inhibitors [98], and glucosylceramide and galactosylceramide synthase inhibitor blocked the germination and hyphal growth of Aspergillus nidulans [99]. An increasing threat is the progressive development of drug resistance to currently available antifungal drugs. Thus, there is an urgent need for antifungal compounds with novel mechanisms of action. The direct use of sphingosine as an antifungal agent was shown in 1992 when Bible et al. proved that sphingosine has antifungal activity against Candida albicans. Sphingosine was found to be fungistatic and could prevent germination and delay thalli formation [33]. The application of sphingosine might disrupt the balance of eukaryotic sphingolipid metabolism and affect the growth of fungi. Further reports on the utility of sphingosine as an antifungal agent are pending.

\section{Conclusions}

Sphingosine, as a lipid common to the skin and oral cavity, has remarkable antimicrobial activities against a variety of Gram-positive and Gram-negative bacteria, viruses, and fungi (Table 1). The presented review indicates that sphingosine may be useful as a coating for plastic surfaces and orthopedic implants, thereby preventing bacteria-induced wound infections, and as a medicinal treatment inhaled by the host, i.e., as a protective agent against infections in cystic fibrosis disease. These promising data provide evidence that sphingosine may be a novel antimicrobial agent that can prevent bacterial adherence and induce the killing of pathogens. Therefore, it may contribute to defensive barrier functions and has the potential for use in prophylactic or therapeutic interventions in infection. Sphingosine even seems to positively influence several significant viral infections, such as $\mathrm{HCV}$ and SARS-CoV-2, by interfering with the interaction between the virus and its receptor, and it might be helpful as an antifungal agent. Further preclinical and, eventually, clinical examinations of sphingosine are warranted to evaluate its potential use as a prophylactic or early treatment for microbial diseases. 
Author Contributions: Conceptualization, Y.W., H.G. and E.G.; writing-review and editing, Y.W., Y.L., H.G. and E.G.; funding acquisition, H.G. All authors have read and agreed to the published version of the manuscript.

Funding: The study was supported by D.F.G. grants G.R. 1697/2-1 and 2-2 to H.G.

Institutional Review Board Statement: Not applicable.

Informed Consent Statement: Not applicable.

Data Availability Statement: Not applicable.

Acknowledgments: Not applicable.

Conflicts of Interest: The authors declare no conflict of interest.

\begin{abstract}
Abbreviations
Sphingosine (Sph); Sphingosine-1-phosphate (S1P); Sphingosine kinase (Sphk); Staphylococcus aureus (S. aureus); Pseudomonas aeruginosa (P. aeruginosa); cystic fibrosis (CF); cystic fibrosis transmembrane conductance regulator (CFTR) protein; Neisseria gonorrhoeae ( $N$. gonorrhoeae); hepatitis $\mathrm{C}$ virus (HCV); herpes simplex virus type 1 (HSV-1); severe acute respiratory syndrome coronavirus-2 (SARS-CoV-2); angiotensin-converting enzyme 2 (ACE2); human immunodeficiency virus (HIV)
\end{abstract}

\title{
References
}

1. Futerman, A.H.; Hannun, Y.A. The complex life of simple sphingolipids. EMBO Rep. 2004, 5, 777-782. [CrossRef] [PubMed]

2. Cuvillier, O.; Pirianov, G.; Kleuser, B.; Vanek, P.G.; Coso, O.A.; Gutkind, J.S.; Spiegel, S. Suppression of ceramide-mediated programmed cell death by sphingosine-1-phosphate. Nat. Cell Biol. 1996, 381, 800-803. [CrossRef] [PubMed]

3. Spiegel, S.; Merrill, A.H. Sphingolipid metabolism and cell growth regulation. FASEB J. 1996, 10, 1388-1397. [CrossRef]

4. Bartke, N.; Hannun, Y.A. Bioactive sphingolipids: Metabolism and function. J. Lipid Res. 2009, 50, S91-S96. [CrossRef]

5. Ohanian, J.; Ohanian, V. Sphingolipids in mammalian cell signalling. Cell. Mol. Life Sci. 2001, 58, 2053-2068. [CrossRef] [PubMed]

6. Tirodkar, T.S.; Voelkel-Johnson, C. Sphingolipids in apoptosis. Exp. Oncol. 2012, 34, 231-242.

7. Iessi, E.; Marconi, M.; Manganelli, V.; Sorice, M.; Malorni, W.; Garofalo, T.; Matarrese, P. On the role of sphingolipids in cell survival and death. Int. Rev. Cell Mol. Biol. 2020, 351, 149-195. [CrossRef]

8. Hanada, K. Sphingolipids in infectious diseases. Jpn. J. Infect. Dis. 2005, 58, 131-148.

9. Hannun, Y.A.; Obeid, L.M. Sphingolipids and their metabolism in physiology and disease. Nat. Rev. Mol. Cell Biol. 2018, 19, 175-191. [CrossRef]

10. Olivera, A.; Kohama, T.; Edsall, L.; Nava, V.; Cuvillier, O.; Poulton, S.; Spiegel, S. Sphingosine Kinase Expression Increases Intracellular Sphingosine-1-Phosphate and Promotes Cell Growth and Survival. J. Cell Biol. 1999, 147, 545-558. [CrossRef]

11. Pyne, N.J.; Pyne, S. Sphingosine 1-phosphate and cancer. Nat. Rev. Cancer 2010, 10, 489-503. [CrossRef]

12. Maceyka, M.; Nava, V.E.; Milstien, S.; Spiegel, S. Aminoacylase 1 is a sphingosine kinase 1-interacting protein. FEBS Lett. 2004, 568, 30-34. [CrossRef]

13. Arish, M.; Husein, A.; Kashif, M.; Saleem, M.; Akhter, Y.; Rub, A. Sphingosine-1-phosphate signaling: Unraveling its role as a drug target against infectious diseases. Drug Discov. Today 2016, 21, 133-142. [CrossRef]

14. Hudlicky, T.; Rouden, J.; Luna, H.; Allen, S. Microbial Oxidation of Aromatics in Enantiocontrolled Synthesis. 2. Rational Design of Aza Sugars (endo-Nitrogenous). Total Synthesis of (+)-Kifunensine, Mannojirimycin, and Other Glycosidase Inhibitors. J. Am. Chem. Soc. 1994, 116, 5099-5107. [CrossRef]

15. Tommasino, C.; Marconi, M.; Ciarlo, L.; Matarrese, P.; Malorni, W. Autophagic flux and autophagosome morphogenesis require the participation of sphingolipids. Apoptosis 2015, 20, 645-657. [CrossRef]

16. Olivera, A.; Rosenthal, J.; Spiegel, S. Effect of acidic phospholipids on sphingosine kinase. J. Cell. Biochem. 1996, 60, 529-537. [CrossRef]

17. Smith, E.R.; Merrill, A.H.; Obeid, L.M.; Hannun, Y.A. Effects of Sphingosine and Other Sphingolipids on Protein Kinase C. Methods Enzymol. 2000, 312, 361-373. [CrossRef] [PubMed]

18. Fischer, C.L.; Drake, D.R.; Dawson, D.V.; Blanchette, D.R.; Brogden, K.A.; Wertz, P.W. Antibacterial Activity of Sphingoid Bases and Fatty Acids against Gram-Positive and Gram-Negative Bacteria. Antimicrob. Agents Chemother. 2011, 56, 1157-1161. [CrossRef] [PubMed]

19. Sakamoto, H.; Okamoto, K.; Aoki, M.; Kato, H.; Katsume, A.; Ohta, A.; Tsukuda, T.; Shimma, N.; Aoki, Y.; Arisawa, M.; et al. Host sphingolipid biosynthesis as a target for hepatitis C virus therapy. Nat. Chem. Biol. 2005, 1, 333-337. [CrossRef] [PubMed]

20. Rollin-Pinheiro, R.; Singh, A.; Barreto-Bergter, E.; Del Poeta, M. Sphingolipids as targets for treatment of fungal infections. Futur. Med. Chem. 2016, 8, 1469-1484. [CrossRef] [PubMed] 
21. Pewzner-Jung, Y.; Tabazavareh, S.T.; Grassmé, H.; Becker, K.A.; Japtok, L.; Steinmann, J.; Joseph, T.; Lang, S.; Tuemmler, B.; Schuchman, E.H.; et al. Sphingoid long chain bases prevent lung infection by Pseudomonas aeruginosa. EMBO Mol. Med. 2014, 6, 1205-1214. [CrossRef]

22. Grassmé, H.; Henry, B.; Ziobro, R.; Becker, K.A.; Riethmüller, J.; Gardner, A.; Seitz, A.P.; Steinmann, J.; Lang, S.; Ward, C.; et al. $\beta 1$-Integrin Accumulates in Cystic Fibrosis Luminal Airway Epithelial Membranes and Decreases Sphingosine, Promoting Bacterial Infections. Cell Host Microbe 2017, 21, 707-718.e8. [CrossRef]

23. Tabazavareh, S.T.; Seitz, A.; Jernigan, P.; Sehl, C.; Keitsch, S.; Lang, S.; Kahl, B.C.; Edwards, M.; Grassmé, H.; Gulbins, E.; et al. Lack of Sphingosine Causes Susceptibility to Pulmonary Staphylococcus Aureus Infections in Cystic Fibrosis. Cell. Physiol. Biochem. 2016, 38, 2094-2102. [CrossRef]

24. Carstens, H.; Schumacher, F.; Keitsch, S.; Kramer, M.; Kühn, C.; Sehl, C.; Soddemann, M.; Wilker, B.; Herrmann, D.; Swaidan, A.; et al. Clinical Development of Sphingosine as Anti-Bacterial Drug: Inhalation of Sphingosine in Mini Pigs has no Adverse Side Effects. Cell. Physiol. Biochem. 2019, 53, 1015-1028. [CrossRef]

25. Bibel, D.J.; Aly, R.; Shinefield, H.R. Antimicrobial Activity of Sphingosines. J. Investig. Dermatol. 1992, 98, 269-273. [CrossRef] [PubMed]

26. Fischer, C.L.; Walters, K.S.; Drake, D.R.; Blanchette, D.R.; Dawson, D.V.; Brogden, K.A.; Wertz, P.W. Sphingoid Bases Are Taken Up byEscherichia coliandStaphylococcus aureusand Induce Ultrastructural Damage. Ski. Pharmacol. Physiol. 2013, $26,36-44$. [CrossRef] [PubMed]

27. Verhaegh, R.; Becker, K.A.; Edwards, M.J.; Gulbins, E. Sphingosine kills bacteria by binding to cardiolipin. J. Biol. Chem. 2020, 295, 7686-7696. [CrossRef] [PubMed]

28. Lee, M.H.; Byun, J.; Jung, M.; Yang, J.J.; Park, K.-H.; Moon, S.-Y.; Lee, H.J.; Lee, M.S. Disseminated Gonococcal Infection Presenting as Bacteremia and Liver Abscesses in a Healthy Adult. Infect. Chemother. 2015, 47, 60-63. [CrossRef]

29. Seitz, A.P.; Schumacher, F.; Baker, J.; Soddemann, M.; Wilker, B.; Caldwell, C.C.; Gobble, R.M.; Kamler, M.; Becker, K.A.; Beck, S.; et al. Sphingosine-coating of plastic surfaces prevents ventilator-associated pneumonia. J. Mol. Med. 2019, 97, 1195-1211. [CrossRef]

30. Rice, T.C.; Pugh, A.M.; Seitz, A.P.; Gulbins, E.; Nomellini, V.; Caldwell, C.C. Sphingosine rescues aged mice from pulmonary pseudomonas infection. J. Surg. Res. 2017, 219, 354-359. [CrossRef]

31. Rice, T.C.; Seitz, A.P.; Edwards, M.J.; Gulbins, E.; Caldwell, C.C. Frontline Science: Sphingosine rescues burn-injured mice from pulmonaryPseudomonas aeruginosainfection. J. Leukoc. Biol. 2016, 100, 1233-1237. [CrossRef] [PubMed]

32. Beckmann, N.; Pugh, A.M.; Auteri, N.J.; Edwards, M.J.; Gulbins, E.; Caldwell, C.C. Therapeutic Inhaled Sphingosine for Treating Lung Infection in a Mouse Model of Critical Illness. Cell. Physiol. Biochem. 2020, 54, 1054-1067. [CrossRef]

33. Bibel, D.J.; Aly, R.; Shah, S.; Shinefield, H.R. Sphingosines: Antimicrobial barriers of the skin. Acta Derm. Venereol. 1993, 73, 407-411. [PubMed]

34. Parsons, J.B.; Yao, J.; Frank, M.W.; Jackson, P.; Rock, C.O. Membrane Disruption by Antimicrobial Fatty Acids Releases LowMolecular-Weight Proteins from Staphylococcus aureus. J. Bacteriol. 2012, 194, 5294-5304. [CrossRef]

35. Beck, S.; Sehl, C.; Voortmann, S.; Verhasselt, H.L.; Edwards, M.J.; Buer, J.; Hasenberg, M.; Gulbins, E.; Becker, K.A. Sphingosine is able to prevent and eliminate Staphylococcus epidermidis biofilm formation on different orthopedic implant materials in vitro. $J$. Mol. Med. 2019, 98, 209-219. [CrossRef] [PubMed]

36. Lang, J.; Bohn, P.; Bhat, H.; Jastrow, H.; Walkenfort, B.; Cansiz, F.; Fink, J.; Bauer, M.; Olszewski, D.; Ramos-Nascimento, A.; et al. Acid ceramidase of macrophages traps herpes simplex virus in multivesicular bodies and protects from severe disease. Nat. Commun. 2020, 11, 1-15. [CrossRef]

37. Edwards, M.J.; Becker, K.A.; Gripp, B.; Hoffmann, M.; Keitsch, S.; Wilker, B.; Soddemann, M.; Gulbins, A.; Carpinteiro, E.; Patel, S.H.; et al. Sphingosine prevents binding of SARS-CoV-2 spike to its cellular receptor ACE2. J. Biol. Chem. 2020, 295, 15174-15182. [CrossRef]

38. Burtenshaw, J.M.L. The Mechanism of Self-Disinfection of the Human Skin and its Appendages. J. Hyg. 1942, 42, 184-210. [CrossRef]

39. Arikawa, J.; Ishibashi, M.; Kawashima, M.; Takagi, Y.; Ichikawa, Y.; Imokawa, G. Decreased Levels of Sphingosine, a Natural Antimicrobial Agent, may be Associated with Vulnerability of the Stratum Corneum from Patients with Atopic Dermatitis to Colonization by Staphylococcus aureus. J. Investig. Dermatol. 2002, 119, 433-439. [CrossRef] [PubMed]

40. Martin, G.E.; Boudreau, R.M.; Couch, C.; Becker, K.A.; Edwards, M.J.; Caldwell, C.C.; Gulbins, E.; Seitz, A. Sphingosine's role in epithelial host defense: A natural antimicrobial and novel therapeutic. Biochimie 2017, 141, 91-96. [CrossRef] [PubMed]

41. Tong, S.Y.C.; Davis, J.S.; Eichenberger, E.; Holland, T.L.; Jr, V.G.F. Staphylococcus aureus Infections: Epidemiology, Pathophysiology, Clinical Manifestations, and Management. Clin. Microbiol. Rev. 2015, 28, 603-661. [CrossRef] [PubMed]

42. Paharik, A.E.; Horswill, A.R. The Staphylococcal Biofilm: Adhesins, Regulation, and Host Response. Microbiol. Spectr. 2016, 4. [CrossRef] [PubMed]

43. Murphy, T.F. Pseudomonas aeruginosa in adults with chronic obstructive pulmonary disease. Curr. Opin. Pulm. Med. 2009, 15, 138-142. [CrossRef]

44. Martínez-Solano, L.; Macia, M.D.; Fajardo, A.; Oliver, A.; Martinez, J.L. ChronicPseudomonas aeruginosaInfection in Chronic Obstructive Pulmonary Disease. Clin. Infect. Dis. 2008, 47, 1526-1533. [CrossRef] 
45. Teichgräber, V.; Ulrich, M.; Endlich, N.; Riethmüller, J.; Wilker, B.; De Oliveira-Munding, C.C.; Van Heeckeren, A.M.; Barr, M.L.; Von Kürthy, G.; Schmid, K.W.; et al. Ceramide accumulation mediates inflammation, cell death and infection susceptibility in cystic fibrosis. Nat. Med. 2008, 14, 382-391. [CrossRef] [PubMed]

46. Elborn, J.S. Cystic fibrosis. Lancet 2016, 388, 2519-2531. [CrossRef]

47. O'Sullivan, B.P.; Freedman, S.D. Cystic fibrosis. Lancet 2009, 373, 1891-1904. [CrossRef]

48. Riordan, J.R.; Rommens, J.M.; Kerem, B.; Alon, N.; Rozmahel, R.; Grzelczak, Z.; Zielenski, J.; Lok, S.; Plavsic, N.; Chou, J.L.; et al. Identification of the cystic fibrosis gene: Cloning and characterization of complementary DNA. Science 1989, 245, 1066-1073. [CrossRef]

49. Kerem, B.; Rommens, J.M.; A Buchanan, J.; Markiewicz, D.; Cox, T.K.; Chakravarti, A.; Buchwald, M.; Tsui, L.C. Identification of the cystic fibrosis gene: Genetic analysis. Science 1989, 245, 1073-1080. [CrossRef]

50. Imundo, L.; Barasch, J.; Prince, A.; Al-Awqati, Q. Cystic fibrosis epithelial cells have a receptor for pathogenic bacteria on their apical surface. Proc. Natl. Acad. Sci. USA 1995, 92, 3019-3023. [CrossRef]

51. Becker, K.A.; Riethmüller, J.; Lüth, A.; Döring, G.; Kleuser, B.; Gulbins, E. Acid Sphingomyelinase Inhibitors Normalize Pulmonary Ceramide and Inflammation in Cystic Fibrosis. Am. J. Respir. Cell Mol. Biol. 2010, 42, 716-724. [CrossRef]

52. A Kalanuria, A.; Zai, W.; Mirski, M. Ventilator-associated pneumonia in the ICU. Crit. Care 2014, 18, 208. [CrossRef]

53. Chastre, J.; Fagon, J.-Y. Ventilator-associated Pneumonia. Am. J. Respir. Crit. Care Med. 2002, 165, 867-903. [CrossRef] [PubMed]

54. Darouiche, R.O. Treatment of Infections Associated with Surgical Implants. N. Engl. J. Med. 2004, 350, 1422-1429. [CrossRef]

55. Stewart, P.S.; Costerton, J.W. Antibiotic resistance of bacteria in biofilms. Lancet 2001, 358, 135-138. [CrossRef]

56. McManus, A.T.; Mason, A.D.; McManus, W.F.; Pruitt, B.A. Twenty-five year review ofPseudomonas aeruginosa bacteremia in a burn center. Eur. J. Clin. Microbiol. Infect. Dis. 1985, 4, 219-223. [CrossRef] [PubMed]

57. Brewer, S.C.; Wunderink, R.G.; Jones, C.B.; Leeper, K.V. Ventilator-Associated Pneumonia Due to Pseudomonas Aeruginosa. Chest 1996, 109, 1019-1029. [CrossRef]

58. Vidal, F.; Mensa, J.; Almela, M.; A Martínez, J.; Marco, F.; Casals, C.; Gatell, J.M.; Soriano, E.; De Anta, M.T.J. Epidemiology and outcome of Pseudomonas aeruginosa bacteremia, with special emphasis on the influence of antibiotic treatment. Analysis of 189 episodes. Arch. Intern. Med. 1996, 156, 8862105. [CrossRef]

59. Society, A.T.; America, I.D.S.O. Guidelines for the Management of Adults with Hospital-acquired, Ventilator-associated, and Healthcare-associated Pneumonia. Am. J. Respir. Crit. Care Med. 2005, 171, 388-416. [CrossRef]

60. Morrison, A.J.; Wenzel, R.P. Epidemiology of Infections Due to Pseudomonas aeruginosa. Clin. Infect. Dis. 1984, 6, S627-S642. [CrossRef]

61. Currie, A.J.; Speert, D.P.; Davidson, N.J. Pseudomonas aeruginosa:Role in the Pathogenesis of the CF Lung Lesion. Semin. Respir. Crit. Care Med. 2003, 24, 671-680. [CrossRef] [PubMed]

62. Rao, S. New insights into pulmonary inflammation in cystic fibrosis. Arch. Dis. Child. 2006, 91, 786-788. [CrossRef] [PubMed]

63. Ebenezer, D.L.; Fu, P.; Krishnan, Y.; Maienschein-Cline, M.; Hu, H.; Jung, S.; Madduri, R.; Arbieva, Z.; Harijith, A.; Natarajan, V. Genetic deletion of Sphk2 confers protection against Pseudomonas aeruginosa mediated differential expression of genes related to virulent infection and inflammation in mouse lung. BMC Genom. 2019, 20, 1-19. [CrossRef] [PubMed]

64. Strub, G.M.; Maceyka, M.; Hait, N.C.; Milstien, S.; Spiegel, S. Extracellular and Intracellular Actions of Sphingosine-1-Phosphate. Adv. Exp. Med. Biol. 2010, 688, 141-155. [CrossRef]

65. Muraglia, K.A.; Chorghade, R.S.; Kim, B.R.; Tang, X.X.; Shah, V.S.; Grillo, A.S.; Daniels, P.N.; Cioffi, A.G.; Karp, P.H.; Zhu, L.; et al. Small-molecule ion channels increase host defences in cystic fibrosis airway epithelia. Nat. Cell Biol. 2019, 567, 405-408. [CrossRef]

66. Dowhan, W. MOLECULAR BASIS FOR MEMBRANE PHOSPHOLIPID DIVERSITY:Why Are There So Many Lipids? Annu. Rev. Biochem. 1997, 66, 199-232. [CrossRef]

67. Britigan, B.E.; Cohen, M.S.; Sparling, P.F. Gonococcal Infection: A Model of Molecular Pathogenesis. N. Engl. J. Med. 1985, 312, 1683-1694. [CrossRef]

68. Solger, F.; Kunz, T.C.; Fink, J.; Paprotka, K.; Pfister, P.; Hagen, F.; Schumacher, F.; Kleuser, B.; Seibel, J.; Rudel, T. A Role of Sphingosine in the Intracellular Survival of Neisseria gonorrhoeae. Front. Cell. Infect. Microbiol. 2020, 10, 215. [CrossRef] [PubMed]

69. Yamauchi, Y.; Greber, U.F. Principles of Virus Uncoating: Cues and the Snooker Ball. Traffic 2016, 17, 569-592. [CrossRef] [PubMed]

70. Virgin, H.W. The Virome in Mammalian Physiology and Disease. Cell 2014, 157, 142-150. [CrossRef] [PubMed]

71. Nagy, P.D.; Pogany, J. The dependence of viral RNA replication on co-opted host factors. Nat. Rev. Genet. 2011, 10, 137-149. [CrossRef]

72. Ng, C.G.; Griffin, D.E. Acid sphingomyelinase deficiency increases susceptibility to fatal alphavirus encephalomyelitis. J. Virol. 2006, 80, 10989-10999. [CrossRef]

73. Grassmé, H.; Riehle, A.; Wilker, B.; Gulbins, E. Rhinoviruses Infect Human Epithelial Cells via Ceramide-enriched Membrane Platforms. J. Biol. Chem. 2005, 280, 26256-26262. [CrossRef]

74. Avota, E.; Gulbins, E.; Schneider-Schaulies, S. DC-SIGN Mediated Sphingomyelinase-Activation and Ceramide Generation Is Essential for Enhancement of Viral Uptake in Dendritic Cells. PLoS Pathog. 2011, 7, e1001290. [CrossRef] 
75. Miller, E.H.; Obernosterer, G.; Raaben, M.; Herbert, A.S.; Deffieu, M.S.; Krishnan, A.; Ndungo, E.; Sandesara, R.G.; E Carette, J.; Kuehne, A.I.; et al. Ebola virus entry requires the host-programmed recognition of an intracellular receptor. EMBO J. 2012, 31, 1947-1960. [CrossRef] [PubMed]

76. Grammatikos, G.; Dietz, J.; Ferreiros, N.; Koch, A.; Dultz, G.; Bon, D.; Karakasiliotis, I.; Lutz, T.; Knecht, G.; Gute, P.; et al. Persistence of HCV in Acutely-Infected Patients Depletes C24-Ceramide and Upregulates Sphingosine and Sphinganine Serum Levels. Int. J. Mol. Sci. 2016, 17, 922. [CrossRef]

77. A Karasneh, G.; Shukla, D. Herpes simplex virus infects most cell types in vitro: Clues to its success. Virol. J. $2011,8,481$. [CrossRef] [PubMed]

78. De Nicola, S.; Colombo, M. The eradication of HCV. Minerva Gastroenterol. Dietol. 2016, 62, 63-75. [PubMed]

79. Agelidis, A.M.; Shukla, D. Cell entry mechanisms of HSV: What we have learned in recent years. Future Virol. 2015, 10, 1145-1154. [CrossRef] [PubMed]

80. Weed, D.J.; Nicola, A.V. Herpes simplex virus Membrane Fusion. Met. Norm. Cancer Cells 2017, 223, 29-47. [CrossRef]

81. Fantini, J.; Di Scala, C.; Chahinian, H.; Yahi, N. Structural and molecular modelling studies reveal a new mechanism of action of chloroquine and hydroxychloroquine against SARS-CoV-2 infection. Int. J. Antimicrob. Agents 2020, 55, 105960. [CrossRef] [PubMed]

82. Fantini, J.; Chahinian, H.; Yahi, N. Leveraging coronavirus binding to gangliosides for innovative vaccine and therapeutic strategies against COVID-19. Biochem. Biophys. Res. Commun. 2021, 538, 132-136. [CrossRef]

83. Sorice, M.; Misasi, R.; Riitano, G.; Manganelli, V.; Martellucci, S.; Longo, A.; Garofalo, T.; Mattei, V. Targeting Lipid Rafts as a Strategy Against Coronavirus. Front. Cell Dev. Biol. 2021, 8, 618296. [CrossRef] [PubMed]

84. Zhou, P.; Yang, X.-L.; Wang, X.-G.; Hu, B.; Zhang, L.; Zhang, W.; Si, H.-R.; Zhu, Y.; Li, B.; Huang, C.-L.; et al. A pneumonia outbreak associated with a new coronavirus of probable bat origin. Nature 2020, 579, 270-273. [CrossRef] [PubMed]

85. Hoffmann, M.; Kleine-Weber, H.; Schroeder, S.; Krüger, N.; Herrler, T.; Erichsen, S.; Schiergens, T.S.; Herrler, G.; Wu, N.-H.; Nitsche, A.; et al. SARS-CoV-2 Cell Entry Depends on ACE2 and TMPRSS2 and Is Blocked by a Clinically Proven Protease Inhibitor. Cell 2020, 181, 271-280.e8. [CrossRef]

86. Wrapp, D.; Wang, N.; Corbett, K.S.; Goldsmith, J.A.; Hsieh, C.-L.; Abiona, O.; Graham, B.S.; McLellan, J.S. Cryo-EM structure of the 2019-nCoV spike in the prefusion conformation. Science 2020, 367, 1260-1263. [CrossRef]

87. Lan, J.; Ge, J.; Yu, J.; Shan, S.; Zhou, H.; Fan, S.; Zhang, Q.; Shi, X.; Wang, Q.; Zhang, L.; et al. Structure of the SARS-CoV-2 spike receptor-binding domain bound to the ACE2 receptor. Nature 2020, 581, 215-220. [CrossRef] [PubMed]

88. Wang, Q.; Zhang, Y.; Wu, L.; Niu, S.; Song, C.; Zhang, Z.; Lu, G.; Qiao, C.; Hu, Y.; Yuen, K.-Y.; et al. Structural and Functional Basis of SARS-CoV-2 Entry by Using Human ACE2. Cell 2020, 181, 894-904.e9. [CrossRef] [PubMed]

89. Meacci, E.; Garcia-Gil, M.; Pierucci, F. SARS-CoV-2 Infection: A Role for S1P/S1P Receptor Signaling in the Nervous System? Int. J. Mol. Sci. 2020, 21, 6773. [CrossRef]

90. Pan, Y.; Gao, F.; Zhao, S.; Han, J.; Chen, F. Role of the SphK-S1P-S1PRs pathway in invasion of the nervous system by SARS-CoV-2 infection. Clin. Exp. Pharmacol. Physiol. 2021, 48, 637-650. [CrossRef]

91. Tasat, D.R.; Yakisich, J.S. Rationale for the use of sphingosine analogues in COVID-19 patients. Clin. Med. 2021, 21, e84-e87. [CrossRef]

92. Billich, A.; Bornancin, F.; Dévay, P.; Mechtcheriakova, D.; Urtz, N.; Baumruker, T. Phosphorylation of the Immunomodulatory Drug FTY720 by Sphingosine Kinases. J. Biol. Chem. 2003, 278, 47408-47415. [CrossRef]

93. Obinata, H.; Hla, T. Sphingosine 1-phosphate and inflammation. Int. Immunol. 2019, 31, 617-625. [CrossRef] [PubMed]

94. Perfect, J.R.; Hachem, R.; Wingard, J.R. Update on Epidemiology of and Preventive Strategies for Invasive Fungal Infections in Cancer Patients. Clin. Infect. Dis. 2014, 59, S352-S355. [CrossRef] [PubMed]

95. Obeid, L.M.; Okamoto, Y.; Mao, C. Yeast sphingolipids: Metabolism and biology. Biochim. et Biophys. Acta (BBA) Mol. Cell Biol. Lipids 2002, 1585, 163-171. [CrossRef]

96. McEvoy, K.; Normile, T.G.; Del Poeta, M. Antifungal Drug Development: Targeting the Fungal Sphingolipid Pathway. J. Fungi 2020, 6, 142. [CrossRef]

97. Rodrigues, M.L.; Travassos, L.R.; Miranda, K.R.; Franzen, A.J.; Rozental, S.; De Souza, W.; Alviano, C.S.; Barreto-Bergter, E. Human Antibodies against a Purified Glucosylceramide from Cryptococcus neoformans Inhibit Cell Budding and Fungal Growth. Infect. Immun. 2000, 68, 7049-7060. [CrossRef]

98. Zhong, W.; Jeffries, M.W.; Georgopapadakou, N.H. Inhibition of Inositol Phosphorylceramide Synthase by Aureobasidin A in Candida and AspergillusSpecies. Antimicrob. Agents Chemother. 2000, 44, 651-653. [CrossRef]

99. Levery, S.B.; Momany, M.; Lindsey, R.; Toledo, M.S.; A Shayman, J.; Fuller, M.; Brooks, K.; Doong, R.L.; Straus, A.H.; Takahashi, H.K. Disruption of the glucosylceramide biosynthetic pathway inAspergillus nidulansandAspergillus fumigatusby inhibitors of UDP-Glc:ceramide glucosyltransferase strongly affects spore germination, cell cycle, and hyphal growth. FEBS Lett. 2002, 525, 59-64. [CrossRef] 